\title{
ADDITIONAL RECORDS OF BALD EAGLE PREDATION OF WATERFOWL
}

ROBERT W. NERO, Manitoba Wildlife Branch, 1495 St. James Street, Winnipeg, Manitoba. R3H OW9

Contrary to popular belief, the Bald Eagle is not solely a scavenger, dependent upon dead fish and carrion. The Bald Eagle regularly preys upon injured or grounded waterfowl; as well, it is capable of capturing or knocking down avian prey in flight, including ptarmigan, ducks and geese. As noted in a recent review of this subject, as early as 1880 William Brewster reported Bald Eagles capturing geese in mid-air. ' Avian hunting methods reported by the same authors included capturing birds "on land by approaching close to the ground ... on water by flying low between ocean swells ... diving from a high altitude ... returning to the surface from an underwater dive ... to take sitting birds," and capturing birds, including geese, in flight (as reported by Brewster) by "swooping under the prey, turning upside down, and grasping the breast of the prey with its talons."

The same authors described an adult Bald Eagle pursuing a flock of Snow Geese, catching up with the flock, and then selecting an individual goose which it struck in mid-air. The injured goose and the eagle both landed. Except for the intervention of the observers it was believed that the eagle would have killed the goose. This was at Desoto Lake (lowaNebraska). Although the authors had been studying Snow Geese in the field since 1976, they had not previously seen an eagle in extended pursuit of a Snow Goose. However, they add: "On the basis of the intense response of Snow Geese to flying eagles [unlike Canada Geese and ducks, in their experience], predation may occur more often than our observations indicate."
A Bald Eagle-Snow Goose encounter reported in 1983 in Oklahoma was overlooked. J.L. Norman is quoted as follows: "We were observing waterfowl at Ft. Gibson Res., when a Bald Eagle flew out over the lake and knocked a Snow Goose out of a flock of 20 . The goose fell into the water but was able to dive beneath the surface twice when the eagle came down to pick it up. Finally the goose tired and the eagle caught and killed it on the water. We watched as the eagle tried four times to lift the goose from the water but failed and had to go back to perch and rest. Finally the eagle gave up." 2

In 1985, a party of hunters saw an adult Bald Eagle strike and kill a Snow Goose in mid-air near Whitewater Lake in southwestern Manitoba (pers. corr., 15 October 1985, Hal Duncan). Murray Duncan and Jack and Dennis Johnston were travelling west on old Highway No. 3 just south of Whitewater Lake on 13 October 1985. At 1:30 p.m. a flock of six Snow Geese flying at a height of about 91-110 $\mathrm{m}$ (100-120 yards) crossed the road about $.5 \mathrm{~km}(1 / 4$ mile) ahead of them. "Suddenly a 'bolt from the blue' descended like a rocket to hit one of the geese in mid-air, apparently killing it instantly. All three observers were astounded at the velocity of the dive, its deadly effect, and the force with which it drove the victim to the ground." The attacker, an adult Bald Eagle, followed the dead goose down to the ground while a second adult Bald Eagle soared overhead. The observers saw the dead goose fall about $69 \mathrm{~m}$ ( 75 yards) from the road. The first eagle landed nearby and then flew up at their approach. When they returned a half hour later one 
eagle was eating the goose, and the other was standing about $18 \mathrm{~m}$ (20 yards) away.

A less spectacular Bald Eagle-Snow Goose interaction was observed by Buddy Chuddy on 10 October 1985 (pers. comm.). At 3:30 p.m. about $6 \mathrm{~km}$ (4 mi.) SE of Hodgson, Manitoba, Chuddy saw an adult Bald Eagle flush a feeding flock of 2000-3000 Snow Geese. The flock circled the grain field twice with the eagle in pursuit. Eventually the flock broke up into several groups and in the end the eagle flew off in close pursuit of three geese. Chuddy watched the chase until the birds were out of sight.

An aerial kill of a Mallard by an adult Bald Eagle was observed $32 \mathrm{~km}$ (20 mi.) $\mathrm{S}$ of Raymond, Alberta on 12 October 1985 by Rod More (pers. comm., 20 November 1985). At about 1:30 p.m. while Rod was driving on a gravel road in a treeless farming area divided by irrigation dikes he saw some Canada Geese and Mallards flush. Than a single duck flew past, apparently separated from one of the flocks; the duck was flying fast in an 128 $\mathrm{km}(80 \mathrm{mph}$ ) wind. Suddenly a black object came diving down upon the duck from above - it had its wings tucked in and looked "like a football." The bird, an adult Bald Eagle, opened its wings at the last minute and struck the duck with extended legs. This was about $27 \mathrm{~m}$ (30 yards) ahead of More's vehicle. The duck, driven down at a $45^{\circ}$ angle by the blow, struck the ground and bounced $6 \mathrm{~m}(20$ feet). The eagle flew about $64 \mathrm{~m}$ (70 yards) into the field, then turned back and landed beside the duck. It flew off as the vehicle approached. The duck, a drake Mallard, was lying on its back with its feet still moving. Its breast was stained almost solid green from having slammed into grass. Upon examining the duck, Rod found three or four shallow holes, bleeding slightly, in the center of its back.

I am grateful to Ken DeSmet for the reference from American Birds. Thanks are due Buddy Chuddy, Hal Duncan and Rod More for their observations.

1 BENNETT, R.S., Jr. and E.E. KLAAS. 1986. Bald Eagle pursues and injures Snow Goose in flight. Raptor Research 20(2):75-76.

2 WILLIAMS, F. 1983. Regional reports. The Winter Season: Dec. 1, 1982-Feb. 28, 1983. Southern Great Plains. American Birds 37(3):314-317.

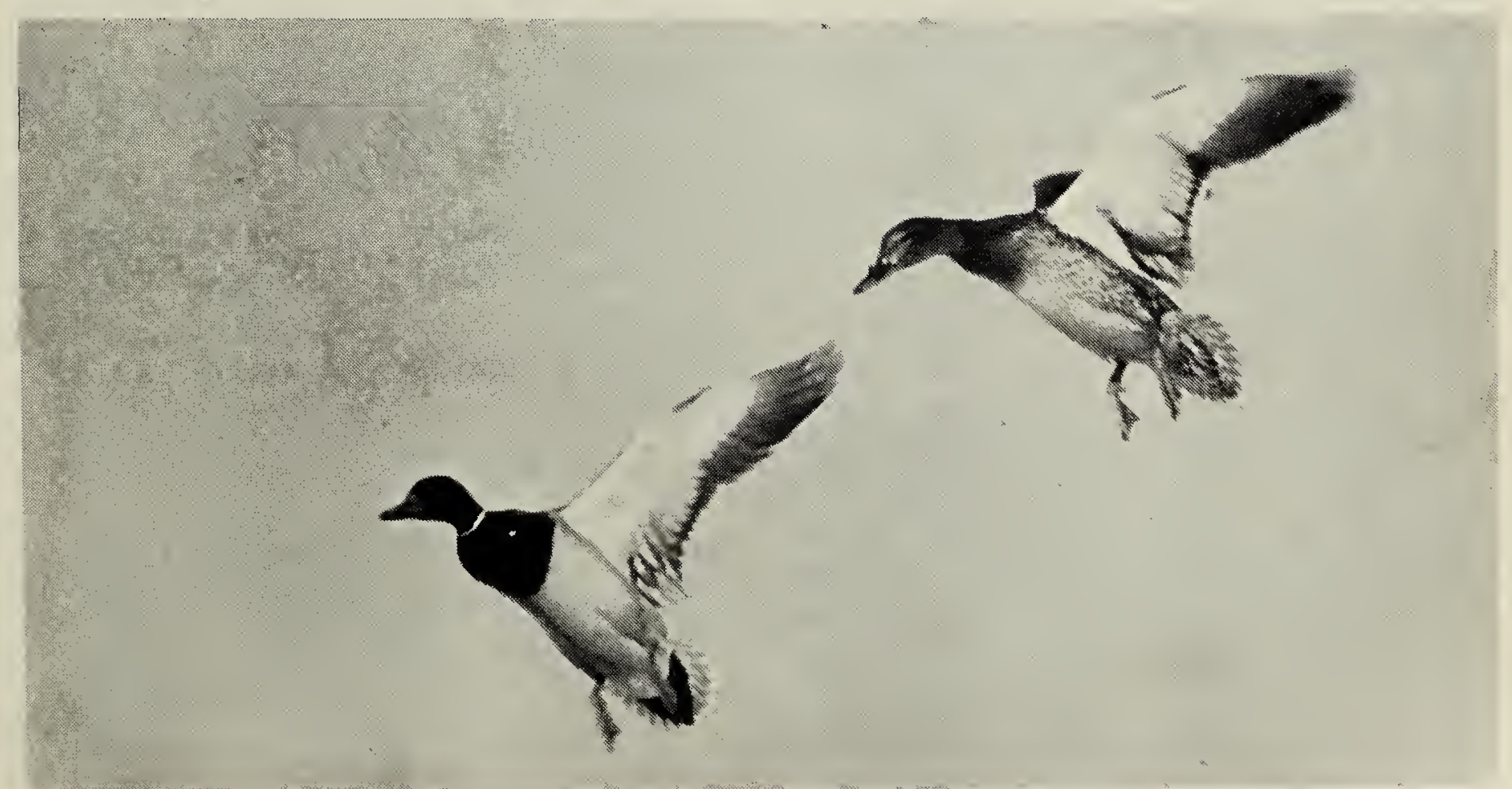

